$\underline{\text { Vol. } 2 \text { No. } 1 \text { (2019) }}$

\title{
PROGRAM DANA HIBAH DALAM PERSPEKTIF POLITIK DISTRIBUTIF: STUDI KASUS PRODAMAS KOTA KEDIRI
}

\author{
Wimmy Haliim \\ Program Studi Ilmu Politik, Fakultas Ilmu Sosial dan Ilmu Politik \\ Universitas Brawijaya \\ wimmyfisip@ub.ac.id
}

\begin{abstract}
The concept of public policy is present and develops as an instrument for the state that aims to prosper the people. In Kediri, there was a public policy called Prodamas. Prodamas is a grant program that is actually presented by the Kediri City government to increase community participation in infrastructure and human development in the City of Kediri. But with a distributive political perspective, Prodamas is seen as a political tool for incumbents, Abdullah Abu Bakar. The indicator, the incumbent campaign program for the Kediri City elections in 2018 is to increase the number of Prodamas funds up to twice (Prodamas Plus), although in practice Prodamas still has many implementation problems. Secondly, the Socialization of Prodamas Plus has been socialized long before the momentum of the Kediri 2018 regional election. Third, Prodamas social assistance which is only given to a number of Kelurahan without clear indicators. Fourth, Prodamas have similarities with other participatory development mechanisms, namely 'Planning and Development Consultation' (Musrenbang). From these indicators, the authors conclude that Prodamas is not only a public policy that is only present for the welfare of the community, but incumbents political tool for political interests in the Kediri City elections 2018.
\end{abstract}

Key Words: Political Distributive, Public Policy, Prodamas, and Incumbent.

Abstrak

Konsep kebijakan publik hadir dan berkembang sebagai sebuah instrument bagi negara yang bertujuan untuk mensejahterakan masyarakatnya. Di Kediri, hadir suatu kebijakan publik yang bernama 'Program Pemberdayaan Masyarakat' (Prodamas). Prodamas adalah program hibah yang sejatinya dihadirkan pemerintah Kota Kediri untuk meningkatkan partisipasi masyarakat dalam pembangunan infrastruktur dan manusia di Kota Kediri. Namun dengan perspektif politik distributif, Prodamas justru terlihat sebagai alat politik petahana, Abdullah Abu Bakar. Indikatornya, tawaran program kampanye petahana untuk pilkada Kota Kediri 2018 adalah meningkatkan jumlah dana Prodamas sampai dengan dua kali lipat (Prodamas Plus), meskipun pada praktiknya Prodamas masih memiliki banyak masalah administratif dan penyerapan anggaran. Kedua, Sosialisasi Prodamas Plus sudah disosialisasikan jauh sebelum momentum pilkada Kota Kediri 2018. Ketiga, bantuan sosial Prodamas yang hanya diberikan kepada beberapa Kelurahan tanpa indikator yang jelas. Keempat, Prodamas memiliki kesamaan implementasi dengan mekanisme pembangunan partisipatif lainnya, yaitu 'Musyawarah Perencanaan dan Pembangunan' (Musrenbang). Dari indikator tersebut, penulis memiliki kesimpulan bahwa Prodamas bukan hanya kebijakan publik yang hanya hadir untuk kesejahteraan masyarakat, namun sengaja disisipi muatan politik, terutama oleh petahana untuk kepentingan politik pada pilkada Kota Kediri 2018. 
Vol. 2 No. 1 (2019)

Kata Kunci: Distribusi Politik, Kebijakan Publik, Prodamas, Petahana.

\section{Pendahuluan}

Menjadikan masyarakat jauh lebih sejahtera merupakan tugas dari hadirnya negara ditengah kehidupan mereka. Maka dari itu, negara berkewajiban untuk merumuskan sebuah formulasi agar bisa mengurai bahkan menyelesaikan problematika yang dihadapi masyarakat. Itulah salah satu alasan konsep kebijakan publik muncul dan berkembang hingga hari ini. Secara umum, kebijakan publik yang dibuat oleh negara bertujuan untuk mengalokasi segala jenis sumber daya yang ada, yang kemudian bisa dibagikan secara proporsional kepada masyarakat. Mengutip Easton (1971) yang menjelaskan, bahwa kebijakan publik sebagai "The Authoritative Allocation of Value For The Whole Society". Didalam beberapa turunan praktik kebijakan publik sesuai dengan penjelasan diatas adalah dalam bentuk program hibah.

Program hibah adalah program pemberian materi atau non-materi (jasa) dari Negara (pemerintah pusat/daerah) kepada pemerintah atau pemerintah daerah lainnya, swasta (perusahaan multinasional/daerah), organisasi kemasyarakatan dan masyarakat. Program hibah biasanya telah diatur secara spesifik tentang penetapan dan peruntukannya. Program hibah memiliki sifat tidak wajib dan tidak mengikat, serta tidak secara terus menerus yang bertujuan untuk menunjang penyelenggaraan urusan pemerintah pusat/daerah (Saragintan \& Hidayat, (2017). Dari berbagai program hibah yang terlaksana d berbagai daerah, Program Pemberdayaan Masyarakat (Prodamas) Kota Kediri lah yang menarik perhatian penulis.
Pertama, Pemerintah Kota

(Pemkot) Kediri merealisasikan Prodamas atau yang lebih dikenal dengan program " $R p .50$ Juta per $R T$ per Tahun" untuk setiap RT yang ada di Kota Kediri. Untuk diketahui, bahwa realisasi Prodamas merupakan janji politik pasangan Walikota, Abdullah Abu Bakar, dan Wakil Walikota, Lilik Muhibbah, saat masa kampanye pilkada 2013 yang lalu dan di implementasikan sejak tahun 2015-sekarang. Prodamas membutuhkan waktu persiapan kurang lebih satu tahun, mulai dari perencanaan program, penerbitan payung hukum (dari perubahan Perwali nomor 52 menjadi nomor 40 tahun 2014), hingga pembentukan tim pengawas Prodamas. Secara umum tujuan dari Prodamas adalah mengurangi peran Pemkot dan menekan partisipasi masyarakat dalam pembangunan (dengan komponen 60\% pembangunan fisik-infrastruktur dan $40 \%$ ekonomi-sosial) (Kedirikota.go.id, 2015).

Kedua, dalam proses berjalannya prodamas, Pemkot Kediri melakukan terobosan dengan meningkatkan level Prodamas kepada tingkat persaingan/kompetisi antar RT se-Kota Kediri. Kompetisi ini ada pada wadah Prodamas Award. Prodamas Award yang sudah memasuki tahap ketiga ini, setidaknya telah melibatkan setidaknya 1.447 RT se-Kota Kediri. Setiap RT akan berkompetisi untuk memperebutkan gelar terbaik dalam bidang-bidang yang sudah ditentukan Pemkot Kediri. Mulai dari bidang pembangunan infratruktur, bidang sosial, dan bidang ekonomi. Terdapat juga bidang khusus yang bisa diperebutkan oleh RT, yaitu bidang 
partisipasi masyarakat dan kinerja ketua RT (Nugroho, 2018).

Ketiga, dampak implementasi Prodamas membuahkan hasil positif bagi kinerja Pemkot Kediri. Januari 2018, Pemkot Kediri menerima anugerah yang cukup bergengsi dalam hal akuntabilitas kinerja yang diberikan oleh Menteri Pendayagunaan Aparatur Negara dan Reformasi Birokrasi (MenPAN-RB) Republik Indonesia. Abdullah Abu Bakar sebagai Walikota Kediri menerima penghargaan Sistem Akuntabilitas Kinerja Instansi Pemerintah (SAKIP) dari menPAN-RB. Penghargaan ini merupakan lompatan besar bagi Pemkot Kediri, karena mampu meningkatkan predikat $\mathrm{CC}$ menjadi predikat $\mathrm{B}$ dalam akuntabilitas kinerjanya (Nugroho, 2018).

Keempat, yaitu Prodamas menjadi program unggulan dari 10 Program yang dikampanyekan oleh pasangan petahana, Abdullah Abu Bakar dan Lilik Muhibbah pada pilkada Kota Kediri 2018. Tidak sampai disitu, dana hibah yang disiapkan untuk Prodamas (Prodamas plus) meningkat dari 50 juta per tahu per RT, menjadi 100 juta per tahun per RT. Dari sinilah, penulis memiliki hipotesa bahwa Prodamas tidak hanya menjadi kebijakan publik yang bertujuan untuk memacu pembangunan infrastruktur maupun suprastruktur di Kota Kediri, namun juga menjadi political agenda berkelanjutan yang dilakukan oleh petahana untuk mengarungi momen politik di pilkada Kota Kediri tahun 2018. Dan dampaknya pun nyata, pasangan petahan memangkan kontestasi pilkada Kota Kediri dengan meraup suara sebanyak 85.514 (sebelumnya, pasangan yang sama meraup suara sebanyak 67.915 pada pilkada Kota Kediri 2013) suara dari keseluruhan 485 TPS yang ada di Kota Kediri (KPU Kediri Kota, 2018)

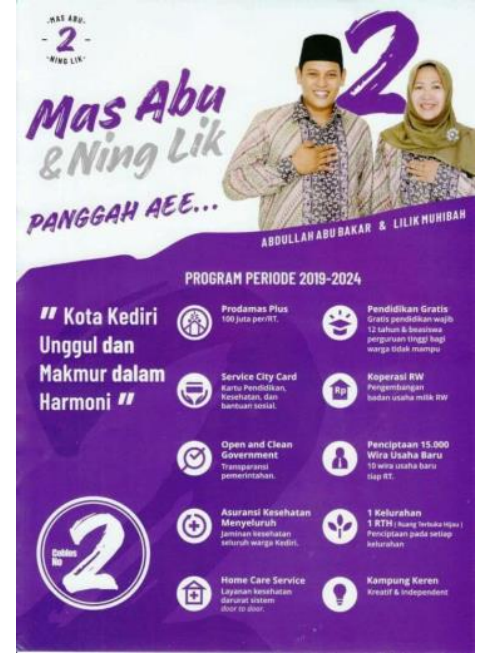

Gambar 1:

10 Program yang dikampanyekan pasangan Abdullah Abu Bakar dan Lilik Muhibbah (Sumber: Duta, 2018)

Disisi lain, Prodamas bukanlah program yang hadir bukan tanpa persoalan di tengah masyarakat Kota Kediri. Persoalan tersebut dimuliai dari audit yang lemah, banyaknya Ketua RT yang belum memahami alur perencanaan hingga bentuk pertanggungjawabannya, pengerjaan proyek yang belum tuntas hingga pengadaan fiktif yang terjadi di beberapa RT (Kurniawan, 2015; Wasono, 2017; Uula 2018). Namun yang terjadi di pilkada 2018, persoalan diatas ternyata tidak mengurangi elektabilitas pasangan petahana. Suara yang diraup pasangat justru meningkat dari pada pilkada Kota Kediri 2013.

Ada beberapa penelitian terdahulu yang menjelaskan bahwa programprogram yang bersifat materi (dana hibah hingga bantuan sosial) yang dilakukan oleh pemerintah daerah rentan sekali kaitannya dengan politik elektoral. Diantaranya adalah Politisasi Program Keluarga Harapan pra-pilgub Jawa Timur 2018 (Haliim, 2018), Fenomena Pork barrel dalam kasus dana hibah dan bantuan sosial Provinsi 
Banten 2011 (Saragintan \& Hidayat, (2017), hingga politik penyusunan anggaran dalam penggunaan dana hibah di Kota Surakarta menjelang pilkada 2010 (Harsasto, 2015). Fenomena tersebut hanya bisa dilakukan oleh elit politik yang memiliki akses birokrasi (terutama calon petahana) untuk merencanakan suatu program sampai dengan distribusi anggaran yang bersifat materiil hingga sosial yang memang diatur sedemikian rupa untuk kepentingan elektabilitas mereka. Susan Stokes (2013) menyebutnya dengan politik distributif.

Politik distributif adalah perspektif yang memberikan pemahaman bahwa kepada kita, bahwa politik (melalui lembaga politiknya: eksekutif-legislatif) sebagai wadah bagi politisi untuk melakukan distribusi dan alokasi sumber daya. Yang dimaksud sumber daya adalah segala sesuatu yang dapat memampukan hingga memberdayakan masyarakat dalam hubungan kuasanya dengan pengelolanya, dalam hal ini bisa birokrat maupun politisi yang terpilih menjadi pejabat publik. Sumber daya juga sering dimaknai sebagai hal baik yang bersifat materiil maupun sosial (Wardani 2014). Jadi, pemaknaan distribusi sumber daya yang termanifestasikan dalam bentuk kebijakan publik, tidak dapat dilepaskan dari kepentingan politik para aktor perumusnya.

Stokes (2013) juga menjelaskan, apabila para pemegang otoritas politik yang berorientasi pada pemenangan pemilu mereka berikutnya, distribusi sumber daya akan menjadi strategi politik unggulan mereka. Kasus prodamas Kota Kediri, Abdullah Abu Bakar sebagai calon petahana di pilkada 2018 Kota Kediri, memperlihatkan kecenderungannya sebagai politisi telah meninjeksikan kepentingan politiknya pada Prodamas agar terpilih kembali.
Pertama, Prodamas sebagai proses distribusi dana-dana pembangunan fisik-sosial Kota Kediri dari APBD langsung ke masyarakat. Kedua, peningkatan dana Prodamas yang menjadi sebesar 100 juta per tahun per RT menjadi tawaran politik dalam kampanye calon petahana pada pemilu kedua mereka.

Jadi, didalam artikel ini Prodamas Kota Kediri tidak hanya dipandang sebagai kebijakan publik biasa. Dengan perspektif politik distributif, penulis bertujuan untuk menjelaskan kepada pembaca bahwa sebuah kebijakan publik (Prodamas) tidak dapat dipisahkan dengan agenda politik penguasa, terutama para petahana. Tujuan agenda politik tersebut adalah untuk melanggengkan ataupun mempertahankan kekuasaan petahana melalui kemampuan distribusi sumberdaya pada program hibah yang dikelolanya.

\section{Metode}

Metode studi kasus berfokus kepada spesifikasi kasus dalam suatu kejadian, baik yang mencakup kasus yang dialami oleh individu maupun sebuah kelompok masyarakat (Lewis, 2015). Mulyadi (2011) menjelaskan metode studi kasus memiliki beberapa ciri, pertama penulis akan melalukan identifikasi permasalahan tentang sebuah fenomena atau kasus tertentu yang dinilai memiliki keunikan dengan fenomena sosial lainnya. Kedua, penulisan metode studi kasus bisa memberikan informasi dan gambaran yang spesifik dan mendalam terkait dinamika dari fenomena ataupun kasus yang akan dibahas. Ketiga, penulisan dengan metode studi kasus membantu penulis untuk menggambarkan secara jelas setting maupun konteks untuk suatu kasus yang menandakan bahwa suatu 
kasus dapat dikaji menjadi sebuah objek studi.

Batasan pembahasan penulisan artikel ini adalah memberikan penjelasan bertahap, yaitu menjelaskan Prodamas sebagai sebuah kebijakan publik dan Prodamas dalam perspektif politik distributif. Batasan lokasi untuk penulisan artikel ini berada di Kota Kediri, karena Prodamas adalah program yang spesifik ada di Kota Kediri. Metode pengumpulan data dilakukan penulis dengan cara observasi lapangan, wawancara, dan studi literatur.

\section{Pembahasan \\ Prodamas Sebagai Sebuah Kebijakan Publik}

Tujuan penulis ingin menjelaskan terlebih dahulu Prodamas sebagai sebuah kebijakan publik adalah, penulis ingin menjelaskan kepada pembaca, bagaimana proses perancangan program/ kegiatan yang dilakukan oleh pihak RT. Berikutnya, penulis juga akan menjelaskan bagaimana koordinasi antar lembaga dalam implementasi Prodamas. Sehingga kita semua mengetahui bagaimana alur administrasi Prodamas dari perencanaan hingga pelaksanaan.

Prodamas dirancang untuk meningkatkan partisipasi masyarakat secara maksimal disemua tahapan Prodamas, mulai dari perencanaan anggaran, implementasi, menentukan jenis pembangunan infrastruktur hingga penggelolaan setiap kegiatan ataupun programnya. Prodamas diatur oleh Peraturan Walikota Kediri Nomor 40 Tahun 2014 tentang Pedoman Pelaksanaan Program Fasilitasi Pemberdayaan Masyarakat. Implementasi Prodamas bertujuan untuk memacu sekaligus mendorong masyarakat untuk ikut serta dalam program-program pembangunan diwilayahnya sendiri (lingkungan RT). Prodamas juga mendukung masyrakat untuk meningkatkan sarana dan prasarana yang ada di lingkungan RT.

Keterlibatan masyarakat RT menjadi faktor penting dan krusial dair implementasi Prodamas. RT lah yang menjadi lembaga parling sentral yang bisa memahami dan menguasai lingkungannya dalah bidang, sosial, ekonomi, hingga kebutuhan infrastruktur. Masyarakat RT merupakan aktor utama yang paling mengetahui permasalahan yang sedang dihadapi serta mengetahui potensi yang dimiliki oleh masyarakatnya. Sehingga, keterlibatan masyarakat sangat diperlukan dalam segala bentuk perencanaan pembangunan dengan mekanisme musyawarah.

Mekanisme berikutnya yang harus dilewati oleh RT dalam Prodamas adalah sosialisasi Prodamas yang dilakukan oleh Ketua RT kepada masyarakatnya. Setelah itu, Ketua RT mentabulasi data usulan kegiatan berdasarkan hasil diskusi masyarakat, untuk menyampaikan usulan kegiatan atau pengadaan barang hasil diskusi, masyarakat melalui diskusi tersebut menentukan prioritas kegiatan/ pekerjaan dan volume kegiatan/ pekerjaan di lengkapi dengan berita acara diskusi masyarakat yang ditujukan kepada Walikota (melalui lurah setempat). Berdasarkan prioritas kegiatan hasil dari diskusi tersebut, kemudian dilakukan sinkronisasi usulan perencanaan tingkat RT oleh Ketua RW. Ketua RW bertugas memadukan usulan perencanaan kegiatan dari masing-masing RT yang berada pada diwilayahnya serta melakukan monitoring pelaksanaan Prodamas.

Selanjutnya adalah pada tingkat kelurahan yaitu pejabat yang ditunjuk oleh Lurah. Lurah bertugas untuk menghimpun, verifikasi data dan 
menyusun daftar rekapitulasi kegiatan berdasarkan prioritas dari seluruh rencana kegiatan yang diusulkan oleh RT. Kemudian Lurah menetapkan daftar rekapitulasi kegiatan dari masingmasing RT untuk di teruskan ke tim koordinasi Prodamas di tingkat yang lebih tinggi, yaitu koordinasi tingkat Kecamatan dan Kota. Pada koordinasi tingkat kecamatan, camat selaku ketua tim koordinasi Prodamas tingkat kecamatan melakukan rekapitulasi seluruh rencana kegiatan/ program dari masing-masing kelurahan di dalam wilayah kerjanya untuk di laporkan kepada tim koordinasi Prodamas tingkat Kota. Selanjutnya tim koordinasi Prodamas tingkat kota melakukan koordinasi seluruh perencanaan kegiatan/ program yang sudah diverifikasi bersama masing-masing kecamatan. Kepala Badan perencanaan pembangunan daerah (Bappeda) selaku Ketua Tim Koordinasi Prodamas Tingkat Kota merekap seluruh rencana kegiatan/ program dari masing-masing kecamatan untuk dijadikan bahan penyusunan rencana kerja pemerintah Kota Kediri.

Prodamas yang berada dibawah koordinasi langsung dari Walikota Kediri, Abdullah Abu Bakar, sebagai komando tertinggi pada Tim koordinasi Prodamas tingkat kota dan tenaga pendamping. Tim koordinasi kota berada dibawah koordinasi langsung Bappeda Kota Kediri. Bappeda berkoordinasi dengan beberapa Organisasi Pemerintah Daerah (OPD) yaitu Kantor Pemberdayaan Masyarakat dan Dinas Pendapatan, Pengelolaan, Keuangan dan Asset Kota Kediri. Tim koordinasi tingkat kota memiliki tugas untuk melaksanakan sosialisasi tentang pelaksanaan Prodamas, memberikan bimbingan teknis yang mencangkup perencanaan kepada tenaga pendamping Prodamas, pelaksanaan dan penyusunan laporan pertanggung jawaban kegiatan, dan melakukan kegiatan monitoring dan evaluasi (monev) seluruh pelaksanaan Prodamas. Tim koordinasi Prodamas tingkat kota memonitoring dan mengevaluasi kepada tim koordinasi Prodamas Kecamatan, tim koordinasi Prodamas Kecamatan memonitoring dan evaluasi tim koordinasi Prodamas kelurahan, dan tim koordinasi kelurahan memonitoring dan mengevaluasi terhadap tim swakelola Prodamas.

Tim koordinasi Prodamas kota memberikan intruksi kepada tim koordinasi tingkat kecamatan untuk melaksanakan sosialisasi tentang pelaksanaan Prodamas, mengkoordinasi pelaksanaan Prodamas pada kelurahan diwilayahnya. Tim Koordinasi tingkat kecamatan melaksanakan pendampingan kepada kelurahan dalam pengelolaan dana Prodamas, melakukan pengendalian dan pemantauan pelaksanaan Prodamas pada kelurahan diwilayahnya. Selain itu, mereka juga membantu dan memberikan saran dan masukan terhadap permasalahan yang timbul dalam pelaksanaan Prodamas, dan melaporkan perkembangan pelaksanaan Prodamas secara rutin setiap triwulan kepada walikota melalui Kantor Pemberdayaan Masyarakat.

Kemudian tim koordinasi kecamatan memberikan intruksi kepada tim koordinasi Prodamas kelurahan. Tim koordinasi Prodamas tingkat kelurahan memiliki tugas untuk melaksanakan sosialisasi tentang pelaksanaan Prodamas, mengkoordinasikan pelaksanaan Prodamas pada tiap RT diwilayahnya, melakukan monev implementasi Prodamas pada tiap-tiap RT di wilayahnya, dan membantu dan memberikan saran dan masukan terhadap permasalahan yang timbul dalam pelaksanaan Prodamas. 
Tim koordinasi kelurahan memberikan intruksi kepada tim swakelola Prodamas yang ada di tingkat RT. Tim swakelola Prodamas mempunyai tugas yaitu menyusun rencana kegiatan secara komprehensif. Rencana kegiatan tersebut berisikan Rencana Anggaran Biaya, membuat gambaran pelaksanaan pekerjaan, Kerangka Acuan kerja dan membuat rencana kerja spesifikasi teknis. Mereka juga bertanggung jawab untuk melaksanakan pekerjaan sesuai dengan yang direncanakan, membuat laporan pelaksanaan pekerjaan, dan melakukan pengawasan terhadap pelaksanaan pekerjaan dan pelaporan baik fisik maupun administrasi dari implementasi Prodamas yang mereka lakukan.

Prodamas juga memperkerjakan tenaga tambahan yang berfungsi untuk mendampingi RT hingga kelurahan dalam implementasinya, mereka bernama Tenaga Pendamping Prodamas. Mereka bertugas untuk mendampingi pada tim koordinasi Prodamas kelurahan dan tim swakelola Prodamas. Tenaga pendamping dalam pelaksanaan tugasnya bertanggung jawab kepada kepala Kantor Pemberdayaan masyarakat.

Kalau kita amati dari setiap proses yang sudah dijabarkan oleh penulis diatas, proses Prodamas mirip dengan proses Musyawarah Perencanaan dan Pembangunan yang biasa diadakan di Kabupaten-Kota yang ada di Indonesia. Pertama, usulan yang berasal dari RT, harus disesuaikan dengan skala prioritas yang ada untuk naik ketingkatan berikutnya. Kedua, Bappeda lah yang menjadi koordinator tingkat kota. Kemungkinan yang terjadi adalah, Bappeda pasti akan menyesuaikan usulan tersebut dengan Rencana Pembangunan Jangka Menengah (RPJM) atau Panjang (RPJP) Kota Kediri. Ketiga, Musrenbang sebagai agenda wajib tahunan Kota Kediri ternyata tetap berjalan. Berarti rencana pembangunan Kota Kediri terjadi dua kali, rentan tumpang tindih dan terkesan pemborosan Anggaran Pendapatan dan Belanja Daerah (APBD) Kota Kediri. Perbedaan Prodamas dengan musrenbang hanya pada pendamping Prodamas dan inklusifitas dana perencanaan pembangunan saja.

Jadi, ketika yang menjadi pembeda antara Prodamas dan musrenbang hanya sebatas Tenaga tambahan dan inklusifitas dana, pemerintah Kota Kediri bisa melakukan hal tersebut pada proses musrenbang, dan hal tersebut akan dinilai sebagai inovasi kebijakan. Seharusnya pemerintah Kota Kediri mendorong keterlibatan masyarakat melalui media musrenbang, bukan menciptakan Program seperti Prodamas yang justru memiliki kesan politis didalamnya.

\section{Prodamas dalam Perspektif Politik Distributif}

Politik distributif sebagai suatu strategi politik yang melibatkan partisipasi warga dalam proses penentuan alokasi dan distribusi sumber daya. Strategi ini bisa dilakukan oleh eksekutif dan atau legislatif, dalam hal ini Presiden dan atau DPR, untuk tidak terjebak oleh kepentingan oligarki. Melihat kondisi saat ini potensi dan peluang terbesar justru ada di tangan eksekutif untuk menjalankan strategi ini.

Politik distributif ini bisa dipandang dari dua sudut. Dari sudut pandang penguasa ini merupakan cara dalam mempertahankan kekuasaan dengan pelibatan warga. Sementara dalam sudut pandang masyarakat ini adalah sarana mendapatkan akses terhadap sumber daya dengan melibatkan diri dalam proses alokasi dan distribusinya. Karena warga diberikan ruang untuk terlibat dalam 
perencanaan alokasi dan perencanaan distribusi dari sumber daya.

Menurut

pendapat

Misbachusurrur selaku salah satu RT di kelurahan Ngadisimo, kecamatan Kota, mengungkapkan bahwa Prodamas dilihat sebagai kebijakan yang tidak tepat sasaran dan terkesan mubazir. Dana 50 Juta per tahun yang diterimanya sering kali tidak bisa dihabiskan. Indikatornya, jika pada tahun pertama RT sudah berhasil membangun kebutuhan infrastruktur, tahun berikutnya kebutuhan infrastruktur tidak menjadi prioritas RT. Dampaknya, $60 \%$ dana yang diperuntukkan untuk pembangunan tidak akan terpakai dengan maksimal. Dampaknya, kecenderungan perilakuperilaku korup bisa saja terjadi, salah satunya adalah penggelembungan dana (mark-up) pada proses penganggaran proposal Prodamas.

Abdullah Abu Bakar juga melakukan beberapa manuver politik untuk mendapatkan citra positif dari masyarakat ketika mendekati momentum pilkada. Januari 2018, Abu Bakar yang masih aktif menjadi Wali Kota Kediri ternyata sudah melakukan sosialisasi program Prodamas Plus, sebuah program yang nantinya dijadikan salah satu kampanye politik didalam pilkada. Selain melakukan sosialisasi Prodamas Plus, Abu Bakar juga memberikan bantuan sosial yang hanya diberikan hanya kepada kepada beberapa kelurahan. Bantuan sosial atas nama Prodamas tersebut diserahkan kepada Kelurahan Mojoroto sebanyak 300 penerima, Kelurahan Bujel sebanyak 245 penerima dan Kelurahan Pojok sebanyak 100 penerima bantuan sosial (Saichu, 2018). Tindakan ini dinilai politis dilihat dari beberapa aspek, pertama, sosialisasi program sudah disampaikan terlebih dahulu jauh sebelum masa kampanye. Kedua, bantuan sosial atas nama Prodamas yang diserahkan kepada beberapa kelurahan tidak memiliki indikator yang jelas.

Ulasan diatas termasuk penerapan politik distributif karena berkaitan dengan pemanfaatan program-program negara atau program pemerintah untuk meraih kemenangan pada pemilu. Oleh sebab itu, politik distribusif dalam hal ini akan lebih cenderung menguntungkan partai penguasa ataupun petahana. Hal demikian dikarenakan petahana kemungkinan memiliki kontrol secara lebih ekslusif dalam memanfaatkan keberhasilan program-program pemerintah (Stokes dalam Palenewen 2014). Berikut ini merupakan gambaran distribusi sumber daya yang dilakukan oleh pemerintah:

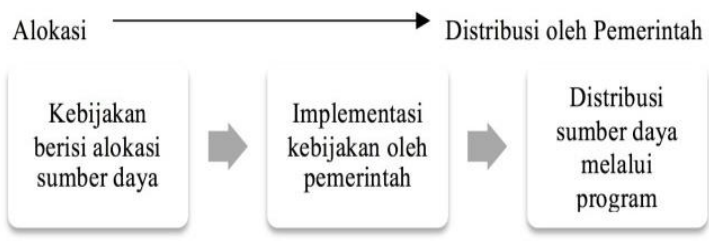

Gambar 2:

Distribusi Sumber Daya

(Sumber: Buku Panduan Pendidikan Pemilih tentang Transaksi Politik dalam Pemilu, dalam Saragintan, 2017).

Secara garis besar, penerapan politik distributif dapat dibagi menjadi dua, yaitu programatik (programmatic) dan non-programatik (non-programmatic) (Stokes dalam Palenewen 2014; Stokes et.al. 2013; Wardani 2014). Dalam politik distributif yang bersifat programatik ada peran perantara yang sifatnya bukan mobilisasi pilihan politik warga untuk kepentingan kandidat atau menjadi mediator yang mempertemukan kepentingan kandidat dengan warga pemilih. Perantara tersebut memiliki peranan sebagai pengumpul informasi dan aspirasi warga terkait permasalahan dan kebutuhan yang dihadapi warga. 
Informasi dan aspirasi yang dihimpun nantinya dijadikan sebagai tuntutan sebagai bentuk penyelesaian permasalahan (Stokes dalam Palenewen 2014).

Dalam politik distributif yang programatik, paling tidak ada dua hal yang perlu diperhatikan (Stokes et.al, 2013). Pertama, kriteria dari pendistribusiannya harus bersifat publik. Seringkali, meski tidak selalu, sebuah diskusi publik mendahului pembuatan regulasi atau kebijakan dalam politik distributif serta implementasiannya. Kedua, kriteria formal dari distribusi harus benar-benar membentuk suatu pendistribu- sian dari sumber daya yang bersangkutan langsung kepada masyarakat.

Sedangkan dalam politik distributif yang bersifat nonprogramatik dibedakan menjadi dua, yaitu klientilisme dan bias partisan. Klientilisme ialah bentuk strategi distribusi ketika kandidat atau partai politik memberikan keuntungan material bagi pemilih dengan syarat pemilih harus memberikan suaranya pada kandidat atau partai tersebut. Pemilih yang tidak memberikan suaranya pada kandidat itu tidak akan mendapat manfaat material dari kandidat (Wardani 2014). Ada beberapa bagian yang tergolong dalam praktik klientilisme, yaitu patronase, jual beli suara, dan constituency service. Seperti yang telah kita tahu, bahwa patronase ialah transaksi yang dilakukan secara individu dan bersifat vertikal, yang biasanya dilakukan terhadap yang memiliki hubungan sebelumnya. Sedangkan servis konstituen memiliki alokasi sumber daya yang berasal dari anggaran negara, namun diberikan dengan sifat personal dan tersegmentasi (Wardani 2014).

Sedangkan strategi distribusi bias partisan dibagi menjadi dua, yaitu program/ kebijakan publik yang bias kepentingan pemilu (electoral diversion of public programs) dan kebijakan politik pork barrel. Bias kepentingan pemilu ialah berkaitan dengan pemahaman bahwa pendistribusian sumber daya pada individu-individu dalam masyarakat dapat meningkatkan dukungan individu tersebut kepada partai atau kandidat yang melakukan distribusi sumber daya. Tidak terdapat konsekuensi bagi individu yang telah mendapat distribusi sumber daya tersebut namun memberikan suara pada partai atau kandidat lain (Palenewen, 2014). Dengan kata lain tidak ada keterikatan atau timbal balik yang pasti berlaku dengan melakukan hal ini.

\section{Kesimpulan}

Perspektif politik distributif melihat prodamas dinilai penulis sebagai program politis yang disiapkan oleh petahana untuk menghadapi momentum pilkada 2018. Alasannya adalah dana yang siap untuk di distribusikan kepada setiap RT meningkat dari 50 juta, menjadi 100 juta per tahun. Kedua, partisipasi masyarakat harusnya bisa ditekan di Musrenbang, bukan membuat program baru seperti Prodamas. Ketiga, Dana Prodamas sering kali tidak bisa dihabiskan. Indikatornya, jika pada tahun pertama RT ternyata sudah berhasil membangun kebutuhan infrastrukturnya, di tahun berikutnya kebutuhan infrastruktur tidak lagi menjadi prioritas RT. Keempat, yang mempertegas bahwa Prodamas digunakan sebagai alat politik petahana adalah sosialisasi Prodamas Plus dengan tawaran meningkatkan dana sebesar $100 \%$ jauh sebelum masa kampanye dinilai sebagai manuver politik petahana. Proses tersebutnya yang dinilai penulis bahwa Prodamas adalah program yang disiapkan petahana untuk mendistribusikan sumber daya yang ada 
kepada masyarakat dengan dalih partisipasi.

\section{DAFTAR PUSTAKA}

Achmad Saichu. (2018). Walikota Kediri Akan Terapkan Prodamas Plus. Dapat diakses di http://koranmemo.com/wali-kotakediri-akan-terapkan-prodamasplus/

Adi Nugroho. (2018). Di Balik Upaya Pemkot Kediri Genjot Akuntabilitas Kinerja: Bukan Zamannya Lagi Program Administratif Semata. Dapat diakses di https://radarkediri.jawapos.com/re ad/2018/02/06/46828/di-balikupaya-pemkot-kediri-genjotakuntabilitas-kinerja-1

Adi Nuhroho. (2018). Prodamas Award: Masuk Tahap Ketiga. Dapat diakses di https://radarkediri.jawapos.com/re ad/2018/03/30/61220/masuktahap-ketiga

Arif Kurniawan. (2015). Takut Terjerat Hukum, Ketua RT di Kediri Wadul Kejari Tekait Prodamas. Dapat diakases di https://www.bangsaonline.com/be rita/10560/takut-terjerat-hukumketua-rt-di-kediri-wadul-kejaritekait-prodamas

Duta.co. (2018). 10 Program Mas AbuNing Lik Jadi Alasan Warga Tidak Pindah ke Lain Hati. Dapat diakses di https://duta.co/10program-mas-abu-ning-lik-jadialasan-warga-tidak-pindah-kelain-hati/

Easton, David. (1971). The Political System: an Inquiry into the State of Political Science. Chicago: University of Chicago Press.

Haliim, W. (2018). Politisasi Program Keluarga Harapan Pada Pilkada Gubernur Jatim 2018: Studi Kasus
Kota dan Kabupaten

Malang. Jurnal Ilmu

Pemerintahan: Kajian Ilmu

Pemerintahan dan Politik

Daerah, 3(1), 43-55.

Hari Tri Wasono. (2017). Pilkada Kota Kediri, Aizzudin dan Sudjono Sebar Surat Terbuka. Dapat diakses di https://nasional.tempo.co/read/9 03385/audit-lemah-programrp50-juta-per-rt-dinilai-rawanbocor

Harsasto, P. (2015). Politik Siklus Anggaran Lokal (Studi APBD Kota Surakarta Menjelang Pilkada 2010). Politika: Jurnal Ilmu Politik, 5(1), 76-87.

Jumadil Uula. (2018). Proyek Prodamas 2017 Tak Tuntas, Pengadaan Tenda RW Diduga Juga Fiktif. Dapat diakses di

https:/hukrim.memontum.com/9047proyek-prodamas-2017-tak-tuntaspengadaan-tenda-rw-diduga-juga-fiktif

Kedirikota .(2015). Walikota Kediri Luncurkan Prodamas. Dapat diakses di https://kedirikota.go.id/prodamas/ bandar_kidul/44

KPU Kediri Kota. (2018). Pilwali Kota Kediri 2018. Dapat diakses di http://rekap.kpukedirikota.go.id/Grafik/?

Lewis, S. (2015). Qualitative inquiry and research design: Choosing among five approaches. Health promotion practice, 16(4), 473475.

Mulyadi, M. (2011). Penelitian kuantitatif dan kualitatif serta pemikiran dasar menggabungkannya. Jurnal studi komunikasi dan media,15(1), 128-137.

Palenewen, Jovano Deivid Oleyver. (2014). Penerapan Patronase dalam Kemenangan Partai 
Keadilan dan Persatuan Indonesia pada Pemilu Legislatif Kota Bitung Tahun 2009. Yogyakarta: Tesis Magister Universitas Gajah Mada.

Saragintan, A., \& Hidayat, S. (2017). Politik Pork Barrel di Indonesia: Kasus Hibah dan Bantuan Sosial di Provinsi Banten tahun 2011. Jurnal Politik,2(1), 137164.

Stokes, Susan, et al. (2013). Brokers, Voters, and Clientelism: The Puzzle of Distributive Politics. New York: Cambridge University Press.

Wardani, Sri Budi Eko. (2014). Buku Panduan Pendidikan Pemilih tentang Transaksi Politik dalam Pemilu. Jakarta: Pusat Kajian Politik UI. 